\title{
TYPES OF EMBEDDED TIES IN BUYER-SUPPLIER RELATIONSHIPS AND THEIR COMBINED EFFECTS ON INNOVATION PERFORMANCE
}

Jon Charterina (University of the Basque Country UPV/EHU)

Imanol Basterretxea (University of the Basque Country UPV/EHU)

Jon Landeta (University of the Basque Country UPV/EHU)

This is an electronic version of the accepted paper in Journal of Business \& Industrial Marketing

The definitive version is available at:

http://www.emeraldinsight.com/doi/full/10.1108/JBIM-04-2014-0071

Please, cite this article as:

Charterina, J., Basterretxea, I., \& Landeta, J. (2016). Types of embedded ties in buyersupplier relationships and their combined effects on innovation performance. Journal of Business \& Industrial Marketing, 31(2), 152-163. 


\title{
TYPES OF EMBEDDED TIES IN BUYER-SUPPLIER RELATIONSHIPS
}

\author{
AND THEIR COMBINED EFFECTS ON INNOVATION PERFORMANCE
}

Purpose of the Paper - This research analyzes the impact of three types of embedded ties, namely, specialized complementary resources, idiosyncratic investments, and knowledge sharing, on the innovation capacity of the firms. We also study the particularities of the Machine-Tool industry.

Theoretical background - Our evaluation of the embedded buyer-supplier ties is based on the potential sources of relational rents proposed by Dyer and Sing (1998). We also draw on Uzzi and Lancaster (2003), Noordhoff et al. (2011), among others, to discuss the positive and negative aspects of embedded ties.

Design/Methodology/Approach - Using data from a survey of 202 European machine-tool firms acting as buyers and sellers, we propose and evaluate a Structural Equation model.

Findings - Only knowledge-sharing routines exert a significant positive effect on product innovation performance. Neither an increase in the idiosyncratic investments nor in complementary resources and capabilities enhance innovation performance. Also, knowledgesharing routines mediate in the effect from idiosyncratic investments on innovation performance.

Research Limitations. - The machine tool industry has unique characteristics that make this generalization difficult. Also, there is considerable difficulty associated with testing more deeply the interrelations among these embedded ties in the long run. It is plausible to understand that these interrelations operate within a gradual process.

Originality/Value/Contribution of Paper - This research contributes to a better understanding of the role of embedded ties on innovativeness. To the best of our knowledge, there is no previous international empirical research analyzing the mediation effects among specialized complementary resources, idiosyncratic investments and knowledge sharing, and their effects on the innovation capacity of firms.

Keywords - Embedded ties, buyer-supplier relationship, Innovation performance, machinetool industry.

\section{JEL CODES}

M11

\section{1.- INTRODUCTION}

During the last two decades, the literature on buyer-supplier relationships has drawn attention to the growing importance of collaborative relationships. In their review of the literature between 1986 and 2005, Terpend et al. (2008) note that during that time-span, there has been a process of moving away from short-term contracting with numerous suppliers (i.e., arm's 
length relationships), to greater commitment by means of longer-term relationships with fewer suppliers, and in the form of embedded ties (Uzzi and Lancaster, 2003). Embeddedness theory has its conceptual roots in sociology (Polanyi, 1957; Granovetter, 1985). According to Granovetter (1985), economic exchanges, rather than being entirely 'rational', are influenced by pre-existing social ties. In fact, he argued that "most behavior is closely embedded in networks of interpersonal relations" (Granovetter, 1985, p. 504) In the literature of buyersupplier ties, many researchers present embedded ties as the opposite of arm's-length ties. The later reflect the conventional view of interfirm ties, where relationships are "cool, impersonal, atomistic, and actors are motivated by instrumental profit seeking" (Uzzy and Lancaster, 2003, p. 384). On the other side, embedded ties "embed their commercial transactions in social attachments and shift the logic of opportunism to a logic of trustful cooperative behavior in a way that creates a new basis for knowledge transfer and learning across firm boundaries" (Uzzy and Lancaster, 2003, p.384). Some authors consider that embeddedness should be treated as a continuous variable rather than as a dichotomy that is either absent or present (Dacin et al., 1999; Andersson et al. 2002); since embedded buyersupplier relationships are not immediately created, but "develop over time from a state characterized by arm's length relationship to relationships based on adaptation and trust" (Andersson et al.. 2002, p. 980)

The process of moving away from arm's length relationship to embedded ties, first implemented by Japanese firms and then emulated by a rising number of companies in the U.S. and other Western Economies, implies greater mutual buyer-supplier efforts in social capital building, investment in relationship-specific assets, improved communication, knowledge sharing and effective governance mechanisms (Dyer and Singh, 1998; Dyer and Nobeoka, 2000). 
The issues and topics analyzed in the literature have gone hand in hand with this process of strengthening inter-firm linkages in the supply chain. Thus, many studies (Provan, 1993; MacDuffie and Helper, 1997; Dyer and Singh 1998; Nooteboom, 1999; Dyer, 2000; Dyer and Nobeoka, 2000; Andersson et al. 2002; Uzzi and Lancaster, 2003; Vickery et al., 2003; Droge et al. 2004; Gulati and Sytch, 2007) have stressed mainly the bright side of "collaborative relationships", "high involvement practices", "quasi-partnerships" or "embedded ties". According to this branch of the literature, close buyer-supplier relationships can generate value and even "collaborative advantages" (Dyer, 2000). Among the reasons given for these advantages, the papers pointing to enhanced innovation by partners (Kaufman et al. 2000; Nooteboom, 1999; Rindfleisch and Moorman 2001; Andersson et al. 2002; Selnes and Sallis, 2003; Uzzi and Lancaster, 2003; Dyer and Nobeoka, 2000; XXX and YYY, 2010) are central to our research. According to these papers, when buyers and suppliers are linked through embedded ties, they gain some positive outcomes such as joint-learning, competence development, faster and enhanced product and process innovations, or early testing of innovations.

Beside those positive effects, a growing number of researchers (Uzzi, 1997; Benseau and Anderson, 1999; Selnes and Sallis, 2003; Anderson and Jap, 2005; Gulati and Sytch, 2007; Broekel and Meder, 2008; Villena et al., 2011, Noordhoff et al., 2011, among them) argue that strong buyer-supplier relationships do not have only a bright side, but also a dark one. These authors highlight some risks of embedded ties, such as partner opportunism, vertical integration, knowledge spill-overs to competitors, knowledge redundancy or loss of objectivity. According to Uzzi (1996, 1997) and Villena et al., (2011), embeddedness yields positive returns only up to a certain threshold. Once this threshold is crossed, the returns from embeddedness become negative, limiting the learning and innovative potential of partners. 
Given the coexistence of one branch of the literature that overwhelmingly stresses the positive side of embedded ties, with another which warns that those ties can also constrain innovation and performance, the present research should shed more light on the debate. In particular, there is a shortage of research addressing the different types of embedded ties; how these interact and how they affect innovation performance. The aim of this research is therefore to analyze the impact of embedded buyer-supplier ties on product innovation performance. To this end, we will draw on a thoroughly identified account of three types of embedded ties, namely specialized complementary resources, idiosyncratic investments, and knowledge sharing, as defined by Dyer and Singh (1998).

In terms of business practice, we aim to gain a more complete understanding of whether the decision to strengthen the buyer-supplier relationship will be associated with product innovativeness. We also want to find out what type of embedded tie would bring more effectiveness for this aim and thus give directions to firms for improving their capabilities for innovation.

In order to accomplish our aim, we have gathered data from a sample of 202 European firms in the machine tool industry. The reason for choosing this particular industry is the importance of buyer-supplier relationships for this sector. Customers are the main source of innovation in the machine tool industry (Carlsson, 1995; Lissoni, 2001, Lissoni and Pagani, 2003; Chen, 2009; Otero, 2010). Machine tool firms innovate as a response to requests from technologically sophisticated users, such as lead firms in the automotive, automation or aircraft industries (Carlsson, 1995; Chen, 2009; Mazzoleni, 1997, 1999). The innovation process in machine tool firms is also favored by trusted highly collaborative local users referred to as "test users" or "machine testers" (Lissoni, 2001; Lissoni and Pagani, 2003; Chen, 2009). These customers enable testing the functionality and reliability of new machines 
in real conditions and help to address and solve otherwise unforeseen problems before the innovated product is widely commercialized.

Suppliers are another important source of innovative products in the industry, especially Computer Numeric Control (CNC) providers (Lissoni and Pagani, 2003; Otero, 2010).

We believe that this sample is also appropriate for testing the propositions of those researchers who highlight the dark side of buyer-supplier embedded relationships. In fact, buyer-supplier interaction is considered as an open door for opportunistic behavior in the sector. Suppliers that opt to create relationships with their buyers, sharing critical knowledge and investing in relationship-specific assets, can lose much of those investments if their partners use the transferred knowledge to vertically integrate and compete directly, a very real risk in the industry (Foxall, 1986; Lee, 1996; Lissoni and Pagani, 2003).

An evaluation of the embedded buyer-supplier ties will be based on the potential sources of relational rents proposed by Dyer and Sing (1998): (1) knowledge-sharing routines; (2) relation-specific assets; and (3) complementary resources and capabilities. The joint effects of those factors on product innovation performance will be measured taking into account two distinctive groups, namely buyers and sellers in a relationship.

The paper is organized as follows. Below, we formulate the hypotheses, based on a review of the literature dealing with the sources of relational rents and their impact on innovation. In the third section, we explain the methodology for our study, and the main results. The fourth section presents our conclusions and considers the theoretical and practical implications. We conclude by highlighting the limitations of the study and the areas that remain open for further research.

\section{2.- BUYER-SUPPLIER EMBEDDEDNESS AND INNOVATION PERFORMANCE}

\section{Innovation performance}


There is a high degree of consensus in both the academic and business spheres that a firm's technological knowledge and its capacity to generate innovation are amongst the most important resources (Galende, 2006). The ability to innovate is a critical source of competitive advantage (Galende and Suárez, 1999).

Despite the substantial increase in the number of empirical studies addressing its role and nature, there is still no widely adopted measurement scale for the concept of innovation (Adams et al., 2006). However, all definitions share a common denominator, the idea of novelty (Damanpour, 1991; Nohria and Gulati, 1996; Johannessen et al., 2001, etc). For its part, innovativeness is more frequently considered as a measure of the degree of 'newness' of an innovation (Garcia and Calantone, 2001). Also, it seems clear that innovativeness is a multifaceted concept and that the use of a single measurement scale may entail problems of content validity (Hadjimanolis, 1997).

However, a counter-argument to the idea of using an overall measurement for innovativeness is that a more specific one could be beneficial if the main purpose of a study is to evaluate specific dimensions or qualities (Wang and Ahmed, 2004). As our research focuses on analyzing competitive advantages that reside in those resources and capabilities originating from relationships with its collaborating agents, particularly customers or suppliers (Dyer 1997, Gulati and Stych 2007), we concentrate on the innovation aspect of product innovation performance.

\section{Knowledge-sharing routines}

Within the innovation process, knowledge has largely been recognized as a critical resource, especially in environments characterized by intense global competition and rapid technological change (Spender and Grant, 1996; Teece 1998). Knowledge management proceeds through three stages: (knowledge) generation, dissemination and application 
(Coombs and Hull 1998; Song et al.2005). In our analysis, the focus is on the dissemination of knowledge between firms in a relationship.

Drawing on Grant (1996), Dyer and Singh (1998) define knowledge-sharing routines among firms as "regular patterns of inter-firm relations that permit the transfer, recombination and creation of specialized knowledge" (p.665). With regard to customer-supplier relationships, in buying or selling complex assets or services, both firms develop capabilities for absorbing mutual knowledge. In this form of inter-organizational learning, a firm acquires the capacity to recognize and assimilate useful knowledge from its relationship partner for pursuing its own interests (Dyer and Singh, 1998).

Partners in dyads with unique fine-grained information exchange may gain a competitive edge by elevating their cognitive capacities and information processing abilities from those of bounded rationality to expert rationality (Uzzi, 1997; Gulati and Sitch, 2007). As innovation is an uncertain process lacking reliable information about latent needs, suppliers can benefit from customer innovation knowledge to generate novel ideas early in the process (Bonner and Walker 2004; Noordhoff et al. 2011). Intense information and knowledge-sharing between buyers and suppliers, increase the probability of discovering new ways to enhance performance (Dyer 1997) and can also be a key factor for process innovations (MacDuffie and Helper 1997, Lin 2007). This might be the case of many machine-tool firms working for large manufacturers in the automotive sector. In this industry, demanding automakers develop their new car models at the same time as machinery-producing firms develop the machines that will be used in production. As a consequence, end-users' needs are transmitted in real time to the machinery supplier firm. This, in turn, will look for innovative solutions for its equipment. Its knowledge of the customer's production process, and how its machines are integrated into it can also provide the customer with ideas for improvement. This process of concurrent engineering will guarantee the necessary communication between the two firms 
We may therefore infer that sharing and exploiting knowledge is linked to a necessary condition of transfer, which in turn necessitates efforts to be made and resources to be dedicated. These include smooth and easy communication, interlocutors who can be asked for or given information, access to technical information that can be given by employees of the customer (supplier) to the supplier (customer), or using technical resources for communication that are compatible with those of the other party. From the joint efforts of the two parties in an industrial supplier-customer relationship intended to share information and gain knowledge, with a view to improving the characteristics of the goods and services that are the object of the commercial exchange, greater product innovation performance can be anticipated, as expressed in the following hypothesis:

H1: A high degree of knowledge-sharing in the customer-supplier relationship is positively related to greater product innovation performance.

\section{Idiosyncratic relationship-specific assets}

Idiosyncratic (relationship-specific) assets refer to investments in physical or human assets that are dedicated to a particular buyer or supplier and whose redeployment entails considerable switching costs (Joshi and Stump, 1999).

Referring to the link between relationship-specific investments and the innovation capabilities of partners, the literature reveals contradictory points of view. According to many authors (Bensaou and Anderson, 1999; Dyer, 1997; Jap and Anderson, 2003; Williamson, 1985), specific investments in a relationship can safeguard it, especially if there is reciprocity and both buyer and supplier invest in assets that are idiosyncratic to the relationship. Bilateral idiosyncratic investments serve as mutual hostages, or as credible commitments by each party to the relationship. They enhance performance outcomes and extend the time horizon of the 
relationship (Jap and Anderson, 2003; Rokkan et al., 2003). Credible commitments via specific investments have been empirically associated with greater cooperation, joint design, better product differentiation, or improved operational performance (Bensaou and Anderson, 1999), factors that can also improve innovation capabilities.

Besides these bonding and positive effects, idiosyncratic investments also involve high risks. If there is no reciprocity, investing in relation-specific assets can create a safeguarding problem (Williamson, 1985), by making the partner's investment vulnerable to opportunistic exploitation by the other partner. Bearing in mind the high risk of opportunistic behavior among buyers and suppliers in the machine-tool industry, one could consider investing in highly specific assets as a risky decision that can jeopardize the firm's performance.

Idiosyncratic investments often involve exclusive relationships with a small number of partners per activity, something that can prejudice innovation (Noteboom, 1999). Due to the exclusiveness of relationships, "variety as a source of innovation within the network may erode and cognitive distance may become too small” (Noteboom, 1999, p. 799).

In the case of the machine-tool industry cited above, a manufacturing firm may come under pressure to make large investments to adopt the same Enterprise Resource Planning (ERP) information system, in order to meet the quality standards in processes that are specific to its customer's activity or to provide technical personnel with the specialization necessary to serve its customer's specific technical needs. Later, these decisions may prove helpful for both parties in achieving innovations or, on the contrary, may be of only limited benefit for maintaining the commercial relationship between the two.

Notwithstanding the abovementioned contradictory ideas in relation to the link between relationship-specific assets and innovation, we propose the following hypothesis with a positive link: 
$\mathrm{H} 2$ : A high level of investment in customer-supplier relation-specific assets is positively related to product innovation performance.

\section{Resource-complementary efforts}

Resource-complementary efforts can be defined as a joint use of distinctive and scarce resources by each partner in the relationship, in such a way that it collectively generates greater outputs than those each party could obtain separately (Dyer and Singh 1998).

Resource complementarity between the parties in a dyad can result from the fact that each one, because it specializes in certain processes or tasks, needs the other to complete a supply process. According to Teece (1986), in nearly all cases, earning extra income from an innovation requires the know-how in question to be used in combination with other capacities and assets.

If a single agent is not capable of procuring all the resources needed to innovate and obtain better performance from it, complementarity must be obtained with the resources and capabilities that other agents can provide. Each party will add resources to the relationship that the other does not have. This is the case in many collaborative relationships between industrial manufacturing firms. Manufacturing of a machine, for instance, commonly involves the joint action of various firms, each bringing its own expertise and specialized components to the firm that is designing and mounting the machine: software, numerical control, motors, cutting tools, etc. The research question here is whether this joint action by different suppliers and customers pooling their complementary resources contributes to the attainment of innovative solutions that surpass those that would come without such interaction.

As in the case of the two previous factors, we consider that the effort devoted to sharing complementary resources and capabilities which are of specialized use with other firms, also 
contributes to obtaining positive results in product innovation performance. This is so, even when their use is not unique (i.e. specific to this relationship). Thus, our hypothesis:

H3: A major effort to complement non-specific mutual resources and capabilities is positively related to product innovation performance.

\section{Interrelations among knowledge-sharing routines, relation-specific assets and complementary resources \& capabilities}

These abovementioned sources of buyer-seller embedded ties do not exist independently. On the contrary, they relate to and reinforce each other over time.

Strong ties between customers and suppliers, such as investments in complementary and specific resources, can exert a positive effect on knowledge transfer and joint-learning (Selnes and Sallis 2003; Uzzi and Lancaster 2003). When firms are linked through strong ties, they tend to transfer more sensitive or private knowledge, and engage in exploratory learning (Uzzi and Lancaster, 2003).

Buyer-supplier strong ties facilitate knowledge exchange between firms, product and process innovation and speed of product development (Rindfleisch and Moorman 2001). An embedded buyer-supplier relationship motivates suppliers to use their own market knowledge to develop innovations in response to customer needs (Dyer and Nobeoka, 2000). Strong relationships also give suppliers an opportunity to test their ideas early in the innovation process and acquire an early understanding of what does and does not improve innovation processes (Noordhoff et al., 2011)

Thus, in a dyadic relationship, it can be assumed that the existence of a series of routines for sharing common knowledge can result from both complementary and idiosyncratic assets. This also implies that there could be a mediation effect of the first element in the relationship 
from either of the two others with respect to innovation performance. Thus, the deployment of specialized assets may be a preliminary stage in a process that evolves into the sharing of idiosyncratic investments. At the same time, it is plausible to consider that the evolving process of these two types of embedded ties will lead to a greater degree of knowledgesharing. Thus, our hypotheses are:

H4: Making a substantial effort to complement specialized (but non-relation-specific) mutual resources and capabilities within a dyad increases the level of investment in relationspecific (idiosyncratic) assets.

H5: Making a substantial effort to complement specialized mutual resources and capabilities within a dyad increases the level of knowledge-sharing of both parties.

H6: A high level of investment in customer-supplier relation-specific assets increases the level of knowledge-sharing effort of both parties.

The proposed hypotheses are illustrated as follows:

\section{--- FIGURE 1 ABOUT HERE ---}

Together with the task of testing the abovementioned hypotheses, we distinguish between indirect and direct effects, by investigating the mediating role of knowledge-sharing routines within the individual effects of idiosyncratic investments and complementary resources. Similarly, we intend to look at the mediation role of idiosyncratic investments within the effect of complementary resources.

\section{3.- EMPIRICAL RESEARCH}


The empirical study was conducted with a sample group of European companies from the socalled Division 28: "Manufacture of machinery and equipment not elsewhere classified", groups 28.4 "Manufacture of metal forming machinery and machine tools", and 28.9 "Manufacture of other special purpose machinery", according to the list of codes from NACE Rev. 2 (2006) $)^{1}$.

The information was gathered by means of telephone interviews with sales, production or management representatives. The interviews were conducted between May and July 2010 by a marketing and social research institute hired for the purpose. The sampling framework consisted of a list of companies from the two abovementioned sub-industries, obtained from Bureau van Dijk's AMADEUS database, valid to March 2010. The profile of contacted managers entailed as a respondent selection criterion based on the random selection of a company as a buyer or a seller firm of machine tool equipment. Respondents were asked to focus on a particular relationship with either a selling or buying firm, preferably from a recent selling or buying operation, for a machine or a fixed asset featuring some sort of innovation, due at least in part to the relationship with that particular client or supplier. Table 1 describes the main features of the sample with regard to the relationship role (buyer or seller firm), country, duration of relationship, and number of employees.

\section{--- TABLE 1 ABOUT HERE ---}

\section{Preparation and testing of the questionnaire}

With respect to the factor Product innovation performance, we formed a scale based on Gemünden, Ritter and Heydebreck (1996), Ritter and Gemünden (2004) and Salomo, Weise and Gemünden (2007). For the remaining factors of the model, we had to almost entirely

\footnotetext{
${ }^{1}$ Regulation (EC) No 1893/2006 of the European Parliament and of the Council of $20^{\text {th }}$ December 2006 establishing the statistical classification of economic activities NACE Revision 2 and amending Council Regulation (EEC) No 3037/90, as well as certain EC Regulations on specific statistical domains. Official Journal of the European Union, 30.12.2006.
} 
develop scales of measurement for the specific study, since we felt that those from the literature did not match the case well or did not suitably define the specific factor we wished to introduce. For all of them, we drew on previous empirical work developed from two of the authors of the present study using only Spanish firms (XXX and YYY, 2010). For the central factors in the model, i.e. Knowledge-sharing routines, Investment in relation-specific assets and Resource and capability-complementary efforts, we used as our basis the original concepts of Dyer and Singh (1998), Dyer and Nobeoka (2000) —although these two seminal works do not propose scales of measurement. We drew on Song et al.'s (2005) concept of Knowledge application, and based our work on its similarity to Knowledge-sharing in order to use its measurement scale.

With respect to the second construct, we drew on Jap (1999). In her study, she defines and incorporates a factor known as Idiosyncratic investments, from which we took one item wordfor-word. We also drew, albeit generically, on some of the previously cited works from the business organization and industrial marketing literature in order to propose a set of items for this construct.

From this theoretical basis, we drew up an initial list of items. This was assessed in relation to the degree of understanding of the items and of content validity (recognizable through whether they were allocated to a single factor or more than one), convergent and discriminant validity (each item in the corresponding factor). This checking task with respect to the allocation of items was completed with the collaboration of a group of 26 lecturers and $\mathrm{PhD}$ students. The improved items were then successively subjected to the judgment of two different research groups. This enabled us to improve and refine the initial list, leaving a minimum of 4 valid items per factor.

\section{Reliability and validity of data}


As previously described, the survey was conducted both with sellers and buyers of machinery. If a measurement scale is to be used in different subpopulations, it is necessary to ensure that the observed variables or scales used are invariant across populations (Mellenbergh 1989, Meredith 1993). There are three increasingly restrictive levels of measurement invariance, namely weak measurement invariance, strong measurement invariance, and strict measurement invariance (Meredith 1993).

According to some references (Byrne, 2006, p.241-246; Hair et al. 2006, p.823; Muthén and Christofferson 1981), weak measurement invariance prevails if equality of factor loadings is ascertained for at least two items per factor. Regarding the scales used here, the incremental Chi-square values obtained ascertain the non-significance in the Chi-square value, due the restriction of equal factor loadings between seller and buyer firms (Table 4). Similarly, the results from the incremental Chi square test from the adjusted structural model, that considers factor correlations equal in both sampling groups, show no significant increase, meaning that invariance again prevails.

In order to analyse the measurement model, we calculate the Cronbach's alpha, average variance extracted (AVE) and construct reliability measures. Although the recommended minimum measurement for the average variances extracted (AVE) measures $(0.50)$ is not exceeded in one of the four factors, the measure of composite reliability exceeds the recommended value of 0.65 in all cases (Fornell and Larcker 1981). The general goodness-offit tests of the model's confirmatory factor analysis yield a good result. Table 2 shows the final set of items that complied with the reliability, validity and measurement invariance tests. The Anderson and Gerbing (1988) Chi-square difference test indicates that there is discriminant validity among the factors, as the general convergence results obtained from setting the highest correlation to 1 yield a significantly higher Chi-square value, meaning a lesser degree of fit than that from the obtained correlation. Also, Anderson and Gerbing's 
(1988) confidence interval test for the bivariate factor correlations do not include the value of 1 in any of their confidence intervals (Table 3, lower left). Furthermore, the Anderson and Gerbing (1988) Chi-square difference test indicates that discriminant validity exists among the factors, as the general convergence results after setting the highest correlation to 1 yield a significantly higher Chi-square value, meaning a lesser degree of fit than that from the correlation. Finally, the square roots from any AVE value obtained (Table 3, principal diagonal values) yield values that do not exceed the correlation from their corresponding row or column (Table 3, upper right) in the case of two factors. However, building on the positive results from the other convergent and discriminant validity tests one may state that these hold support in two of the three tests.

--- TABLE 2 ABOUT HERE ---

--- TABLE 3 ABOUT HERE ---

--- TABLE 4 ABOUT HERE ---

\section{Results}

We used structural equation modelling to test the hypotheses as presented in Figure 1. The lines in Table 5 headed as Hypotheses H1 to H6 reflect direct relationships, whereas the remaining lines show the corresponding indirect relationships. In general, the results for both the total sample and the separate sub-samples are very similar.

With respect to the hypothesized effect of knowledge-sharing routines on product innovation performance, regression coefficients confirm a significant positive relation, meaning that the sharing of knowledge within a relationship seem to exert a positive effect on the innovation 
performance of both firms. Thus, hypothesis H1 is strongly supported. The more knowledge customers and suppliers share, the greater the chances of innovating successfully.

Conversely, the relationship between idiosyncratic assets and innovation performance is found to be negative, albeit non-significant, meaning that hypothesis $\mathrm{H} 2$ is not supported. For the effect of complementary resources and capabilities on innovation performance, although the coefficient is positive, it is again non-significant, meaning that hypothesis $\mathrm{H} 3$ is neither supported. Therefore, neither of these two factors seem to exert a significant direct effect on innovation performance.

Both complementary resources and idiosyncratic investments share a high level of correlation $^{2}$, and correspondingly, a high positive coefficient of regression in the three sets of coefficients. It seems clear from the obtained results that complementary, specialized but not relationship-specific mutual resources and capabilities within a dyad do indeed relate to relation-specific (i.e., idiosyncratic) assets in a relationship. This result strongly supports hypothesis H4. Also, the results support the idea that higher levels of idiosyncratic assets relate to more knowledge-sharing. The regression coefficients reveal a positive relationship between investment in idiosyncratic assets and knowledge sharing. This conforms to hypothesis H6. On the contrary, the relationship from complementary (specific but not idiosyncratic) assets on knowledge sharing is negative in all the cases, and significant in the two sub-samples of buying and selling firms. The results are the converse of the relationship suggested in hypothesis H5. Therefore, it seems that the interrelationships among these three constructs with respect to innovation performance turn out to be even more complex than could be conjectured from analyzing the set of relationships originally described by Dyer and Singh (1998) and thus require further analysis and redefinition, in order to consider this negative effect.

\footnotetext{
${ }^{2}$ From Table 3, it can be seen that it is the square root of the cell in the third row, fourth column, equal to 0.871.
} 
With respect to the set of indirect effects, the results show that there is a mediation effect from the sharing of knowledge in the relationship between idiosyncratic assets and innovation performance. It seems that only to the extent that idiosyncratic assets engender common knowledge in the buyer-seller relationship, are they beneficial to innovation performance. We can interpret from these results that, due to the fact of being closely related to both agents' needs and the higher risk for the investor, idiosyncratic assets tend to promote a more intense interchange of knowledge, resulting in an improvement in innovation capability for both agents. Similar to the results for the direct effects, this is not the case for the mediating role of knowledge sharing between complementary resources and innovation performance, where the obtained regression coefficients indicate a negative, but non-significant effect. Also, from the analysis of the direct effects, it seems clear that it is the mediation effect of idiosyncratic assets in the relationship between complementary assets and knowledge sharing that explains the significantly positive results, in line with hypotheses $\mathrm{H} 4$ and H6. The results also seem to show a positive effect for the serially connected indirect effect among the four constructs, which is shown here with the sole aim of differentiating it from the remaining direct and indirect effects.

Finally, a complementary explanation of our results could lie in the specific features of the machine-tool industry. One common feature is that innovativeness is associated mainly with the objective of providing good responses to customers' specific technological needs (Carlsson, 1995; Chen, 2009; Mazzoleni, 1997, 1999), and with a collaborative relationship aimed at helping customers to succeed at the attainment of good results during the product testing phases (Lissoni, 2001; Lissoni and Pagani, 2003; Chen, 2009). This unique feature seems to entail a significant level of information transmission and sometimes of specific investments. 
In summary, the obtained results show that knowledge-sharing directly influences on innovation performance (as set by hypothesis $\mathrm{H} 1$ ), that complementary resources have a strong influence on the presence of idiosyncratic investments (hypothesis H4), and that, again, idiosyncratic investments have a positive influence on knowledge-sharing (hypothesis H6). We can briefly interpret from these results that, due to the fact of being closely related to both agents' needs and the higher risk for the investor, idiosyncratic assets tend to promote a more intense interchange of knowledge, resulting in an improvement in innovation capability for both agents.

\section{4.- CONCLUSIONS}

This paper contributes to the literature by showing that not every type of embedded tie between customers and buyers does propitiate innovation performance. Some methods of strengthening ties have overwhelmingly positive effects on innovation, while other strategies of tight ties do not generate any effects at all.

Knowledge-sharing routines do exert a positive significant effect on product innovation performance, but neither the increase in idiosyncratic investments nor in complementary resources and capabilities within the buyer-seller relationship seem to lead to an increase in innovation performance.

Our results also indicate that knowledge-sharing routines mediate in the effect of idiosyncratic investments on innovation performance. Therefore, it would be advisable for companies in this sector to dedicate more efforts and resources to sharing information and gaining knowledge in the industrial customer- supplier relationship, in order to improve their product innovation performance. 
On the contrary, it seems potentially risky, and thus inadvisable, to initiate activities that entail the sharing of specialized resources or making of idiosyncratic investments, at least if these are performed with the direct aim of improving the firm's innovative capability. However, if for commercial reasons it becomes necessary, then the agents making such efforts should at least focus on gaining valuable information from the relationship in exchange, as this is the indirect way by which these embedded ties can lead to an improvement in innovative capacity.

Finally, another contribution of this study to the literature refers to the particular effort made to contextualize results, considering the sectoral innovation system of the sample studied. Results and conclusions from previous studies have frequently been generalized and considered valid for different sectors. These generalizations have been even made on the basis of qualitative studies that analyzed the relationship between a single company and its providers. In our research, we consider that some of our results are explainable by the specific sectoral innovation system of the machine-tool industry. Thus, in order to deepen our knowledge of the advantages and disadvantages of embedded buyer-supplier relationships, it is necessary to intensify the analysis of such relationships in different industries.

\section{5.- LIMITATIONS AND FUTURE RESEARCH}

Although the aim of any empirical research should be to draw conclusions that are generalizable to other industries, it is also true that the machine tool industry has peculiarities that make such generalization difficult (Otero 2010). In particular, the relatively large presence of small firms, their dual nature as producers and consumers of machinery, or the fact that many of the studied companies are solely dedicated to producing customized products entailing a high level of investment for their customers, compel us to treat the results with some caution. For example, there is the apparently contradictory role of idiosyncratic 
investments and complementary resources and capabilities, not acting directly as enablers of innovation results, but rather indirectly, as antecedents of knowledge-sharing processes. We suggest that this lack of relationship could be due to a fear of spillover and free-riding risks as mentioned in the revised literature. Further research is needed in order to evaluate and measure the impact of these risks on the decision to invest in complementary resources, idiosyncratic assets and knowledge-sharing procedures.

Also, it is necessary to do more research on enablers for the creation and maintenance of resources and capabilities shared among the supply chain partners, and their effects on innovativeness.

Another limitation of our research involves the difficulties in testing more deeply the interrelationships between $\mathrm{R} \& \mathrm{C}$ complementary efforts, procedures for knowledge sharing and idiosyncratic investments in the long-run. It is plausible that these interrelations operate within a gradual process. Therefore, a long-sectional empirical study of pairs of buying and selling firms would have yielded far more comprehensive results. However, the difficulties associated with such an empirical study are clear.

Lastly, there is one aspect in particular that has been omitted from this research due to its complexity, but it should be investigated in due course, namely, the role of mechanisms of governance (Dyer and Singh, 1998; Wang et al., 2008). Governance mechanisms not only lower or prevent risks and some of the effects discussed above, of opportunism and negative spillovers, but are also a capability in themselves, difficult to imitate and entailing extraordinary rents for the enterprise. Future research efforts should also consider factors such as the use of contracts, and the dynamics of trust or power/dependence.

\section{REFERENCES}


Adams, R., Bessant, J. and Phelps, R. (2006). Innovation management measurement: A review, International Journal of Management Reviews, Vol. 8, No. 1, pp. 21-47.

Anderson, E. and Jap, S.D., 2005. The Dark-Side of Close Relationships, Sloan Management Review, Vol. 46, No. 3, pp. 75-82.

Anderson, J.C. and Gerbing, D.W., 1988. Structural Equation Modeling in Practice: A Review and Recommended Two-Step Approach. Psychological Bulletin, Vol. 103, No.3, pp.411-423

Andersson, U., Forsgren, M. and Holm, U., 2002. The Strategic Impact of External Networks: Subsidiary Performance and Competence Development in the Multinational Corporation. Strategic Management Journal, Vol. 23, pp. 979-996.

Bensaou M. and Anderson, E., 1999. Buyer-supplier relations in industrial markets: when do buyers risk making idiosyncratic investments?. Organization Science, Vol 10, No. 4, pp. 460-481

Bonner, J. M. and Walker, O. C., 2004. Selecting Influential Business-to-Business Customers in New Product Development: Relational Embeddedness and Knowledge Heterogeneity Considerations. Journal of Product Innovation Management, Vol. 21, No.3, pp.155-69.

Broekel, T. and Meder, A., 2008, The bright and dark side of cooperation for regional innovation performance. Paper provided by Utrecht University, Section of Economic Geography in its series Papers in Evolutionary Economic Geography (PEEG), No. 0811. Retrieved from http://econ.geo.uu.nl/peeg/peeg0811.pdfByrne, B., 2006. Structural Equation Modelling with EQS. Basic Concepts, Applications, and Programming. $2^{\text {nd }}$ Edition, Mahwah, NJ: Psychology Press.

Carlsson, B. ed. 1995. Technological Systems and Economic Performance: the case of Factory Automation. Boston: Kluwer Academic Publishers.

Charterina, J. and Landeta, J., 2010, The pool effect of dyad-based capabilities on seller firms' innovativeness. European Journal of Innovation Management, Vol. 13, No.2, pp. 172-196.

Chen, L.C., 2009. Learning through informal local and global linkages: The case of Taiwan's machine tool industry. Research Policy, Vol. 38, pp. 527-535.

Coombs, R. and Hull, R., 1998. Knowledge Management Practices and Path-Dependency in Innovation. Research Policy, 27(3): 237-253. 
Dacin, M. T., Ventresca, M. J. and Beal, B. D., 1999. The embeddedness of organizations: Dialogue \& directions. Journal of management, Vol. 25m No. 33, pp. 317-356.

Damanpour, F., 1991. Organizational innovation: a meta analysis of effects of determinants and moderators. Academy of Management Journal, Vol. 34, No. 3, pp. 555-590.

Droge, C.J.; Jayaram and Vickery, S.K., 2004. The Effects of Internal Versus External Integration Practices on Time-Based Performance and Overall Firm Performance. Journal of Operations Management, Vol.22, No. 6, pp. 557-573.

Dyer, J.H. and Nobeoka, K., 2000. Creating and managing a high-performance knowledge-sharing network: the Toyota case. Strategic Management Journal, Vol. 21, No. 3, pp. 345-67.

Dyer, J.H. and Singh, H., 1998. The relational view: Cooperative strategy and sources of interorganizational competitive advantage. Academy of Management Review, Vol. 23, No. 4, pp. 660-679.

Dyer, J.H., 1997. Effective interfirm collaboration: how firms minimize transaction costs and maximize transaction value. Strategic Management Journal, Vol. 18, No. 7, pp. 535-556.

Dyer, J.H., 2000. Collaborative Advantage: Winning through Extended Enterprise Supplier Networks. Oxford; New York: Oxford University Press.

Fornell, C. and Larcker, D.F., 1981. Evaluating Structural Equation Models with Unobservable Variables and Measurement Error. Journal of Marketing Research, Vol. XVIII (February), pp. 3950.

Foxall, C., 1986. Strategies of User-Initiated Product Innovation. Bedford: Cranfield School of Management.

Galende, J. and Suárez, I., 1999. A resource-based analysis of the factors determining a firm's R\&D activities. Research Policy, Vol. 28, pp. 891-905.

Galende, J., 2006. Analysis of technological innovation from business economics and management. Technovation, Vol. 26, No. 3, pp. 300-311.

Garcia, R. and Calantone, R., 2001. A critical look at technological innovation tipology and innovativeness terminology: a literature review. The Journal of Product Innovation Management, Vol. 19, pp. 110-132. 
Gemünden, H.G.; Ritter, T. and Heydebreck, P., 1996. Network configuration and innovation success: An empirical analysis in German high-tech industries. International Journal of Research in Marketing, Vol. 13, pp. 449-462.

Granovetter, M. 1985. Economic Action and Social Structure: The Problem of Embeddedness. American Journal of Sociology, Vol. 91, No. 3, pp. 481-510.

Grant, R., 1996. Prospering in dynamically-competitive environments: Organizational capability as knowledge integration. Organization Science, Vol. 7, pp. 375-387.

Griliches, Z. and Mairesse, J., 1983. Comparing productivity growth: an exploration of French and US industrial and firm data. European Economic Review, Vol. 21, No.1-2, pp. 89-119.

Griliches, Z. and Mairesse, J., 1990. R\&D and productivity growth: comparing Japanese and US manufacturing firms, in: HULTEN, C., Ed. Productivity Growth in Japan and the United States. pp. 317-348. Chicago: University of Chicago Press.

Gulati, R. and Sytch, M., 2007. Dependence Asymmetry and Joint Dependence in Interorganizational Relationships: Effects of Embeddedness on Exchange Performance. Administrative Science Quarterly, Vol. 52, pp. 32-69.

Hadjimanolis, A., 1997. The management of technological innovation in small and medium sized firms in Cyprus. Doctoral Dissertation. Department of Management Studies. Brunel University.

Hair, Jr., J. F., Black, W. C., Babin, B. J., Anderson, R. E., and Tatham, R. L., 2006. Multivariate Data Analysis, 6th edition, New Jersey: Prentice-Hall.

Jap, S. D. and Anderson, E., 2003. Safeguarding interorganiztional performance and continuity under ex-post opportunisim. Management Science, Vol. 49, No.12, pp. 1684-1701.

Jap, S.D. 1999. Pie-Expansion Efforts: Collaboration Processes in Buyer-Supplier Relationships. Journal of Marketing Research, Vol. XXXVI (November), pp. 461-475.

Johannessen, J-A., Olsen, B. and Lumpkin, G.T., 2001. Innovation as newness: what is new, how new, and new to whom?. European Journal of Innovation Management, Vol. 4, No.1, pp. 20-31.

Joshi, A. W. and Stump, R. L., 1999. The contingent effect of specific asset investments on joint action in manufacturer-supplier relationships: an empirical test of the moderating role of reciprocal 
asset investments, uncertainty and trust. Academy of Marketing Science Journal, Vol. 27, No.3, pp. 291-305.

Kaufman, A., Wood, C.H. and Theyel, G., 2000. Collaboration and Technology linkages: a strategic supplier typology. Strategic Management Journal, Vol. 21, pp. 649-663.

Lee, K.R., 1996. The Role of user Firms in the Innovation of Machine Tools: The Japanese Case. Research Policy, Vol. 25, pp. 491-507.

Lin, H.F., 2007. Knowledge sharing and firm innovation capability: an empirical study. International Journal of Manpower, Vol. 28, No.3-4, pp. 315-332.

Lissoni, F. and Pagani, M., 2003. How many networks in a local cluster? Textile machine production and innovation in Brescia, in: Fornahl, D. and Brenner, T., eds., Cooperation, networks and institutions in regional innovation systems. Cheltenham: Edward Elgar, pp. 220-246.

Lissoni, F., 2001. Knowledge codification and the geography of innovation: The case of Brescia mechanical cluster. Research Policy, Vol. 30, pp.1479-1500.

MacDuffie, J. P. and Helper, S., 1997. Creating lean suppliers: Diffusing lean production through the supply chain. California Management Review, Vol. 39, No. 4, pp. 118-151.

Mairesse, J. and Mohnen, P., 2003. R\&D and productivity: a re-examination in light of the innovation surveys. DRUID Summer Conference 2003. Copenhagen. Denmark.

Mazzoleni, R., 1997. Learning and path-dependence in the diffusion of innovations: comparative evidence on numerically controlled machine tools. Research Policy, Vol. 26, pp. 405-428.

Mazzoleni, R., 1999. Innovation in the Machine-tool Industry: A Historical Perspective on the Dynamics of Comparative Advantage, in: Mowery, D.C. and Nelson, R. R., eds. Sources of Industrial Leadership: Studies of Seven Industries. Cambridge: Cambridge University Press, pp. $169-216$.

Mellenberg, 1989. Item Bias and Item Response Theory, Chapter 1, from Hambleton, R.K. Applications of Item Response Theory, pp.127-143.

Meredith, W., 1993. Measurement Invariance, Factor Analysis and Factorial Invariance, Psychometrika, Vol. 58, No. 4, pp. 525-543. 
Muthén, B. and Christoffersson, A., 1981. Simultaneous factor analysis of dichotomous variables in several groups, Psychometrika, Vol. 46, pp. 407-419.

Nohria, N. and Gulati, R., 1996. Is slack good or bad for innovation?. Academy of Management Journal, Vol. 39, No. 5, pp. 1245-1264.

Noordhoff, C.S.; Kyriakopoulos, K.; Moorman, C.; Pauwles, P. and, Dellaert, G.C., 2011. The Bright Side and Dark Side of Embedded Ties in Business-to-Business Innovation. Journal of Marketing, Vol. 75, No. 5, pp. 34-52.

Nooteboom, B., 1999. Innovation and inter-firm linkages: new implications for policy. Research Policy, Vol. 28, pp. 793-805.

Otero, B., 2010. Made in Euskadi: Innovando en el Sector de Máquina-Herramienta de la CAPV. Doctoral Dissertation. University of the Basque Country.

Polanyi, K., (1957). The Great Transformation. Boston: Beacon Press.

Provan, K. G., 1993. Embeddedness, interdependence, and opportunism in organizational supplierbuyer networks. Journal of Management, Vol. 19, No. 4, pp. 841-856.

Rindfleisch, A. and Moorman, C., 2001. The Acquisition and Utilization of Information in New Product Alliances: A Strength-of-Ties Perspective. Journal of Marketing, Vol. 65, No. 2, pp. 1-18.

Ritter, T. and Gemünden, H.G., 2004. The impact of a company's business strategy on its technological competence, network competence and innovation success. Journal of Business Research, Vol. 57, pp. 548-556.

Rokkan, A. I.; Heide, J. B. and Wathne, K. H., 2003. Specific investments in marketing relationships: expropriation and bonding effects. Journal of Marketing Research. XL, pp. 210-224.

Salomo, S., Weise, J. and Gemünden, H.G., 2007. NPD Planning Activities and Innovation Performance: The Mediating Role of Process Management and the Moderating Effect of Product Innovativeness. The Journal of Product Innovation Management, Vol. 24, pp. 285-302.

Selnes, F. and Sallis, J., 2003. Promoting Relationship Learning. Journal of Marketing, Vol. 67, No. 3, pp. 80-95. 
Song, M. van der Bij, H. and Weggeman, M., 2005. Determinants of the Level of Knowledge Application: A Knowledge-Based and Information-Processing Perspective. Journal of Product Innovation Management, Vol. 22, pp. 430-444

Spender, J.C. and Grant, R.M. 1996. Knowledge and the Firm: Overview. Strategic Management Journal 17:5-9 (Winter Special Issue).

Teece, D.J. 1986. Profiting from Technological Innovation. Research Policy, Vol. 15, no. 6, pp. 285305.

Teece, D.J. 1998. Capturing Value from Knowledge Assets: The New Economy, Market for KnowHow and Intangible Assets. California Management Review, Vol. 40, No.3, pp. 55-79.

Terpend, R., Tyler, B.B., Krause, D.R. and Hanfield, R.B., 2008. Buyer-supplier relationships: derived value over two decades. Journal of Supply chain Management, Vol. 44, No. 2, pp. 28-55.

Uzzi, B. and Lancaster, R., 2003. Relational Embeddedness and Learning: The Case of Bank Loan Managers and their Clients. Management Science, Vol. 49, No. 4, pp. 383-99.

Uzzi, B., 1996. The sources and consequences of embededness for the economic performance of organizations: the network effect. American Sociological Review, Vol. 61, No. 4, pp. 674-698.

Uzzi, B., 1997. Social structure and competition in inter-firm networks: The paradox of embeddedness. Administrative Science Quarterly, Vol. 42, pp. 35-67.

Vickery, S.K., Jayaram, J., Droge, C. and Calantone, R., 2003. The effects of an integrative supply chain strategy on customer service and financial performance: an analysis of direct versus indirect relationships. Journal of Operations Management, Vol. 21, pp. 523-539.

Villena, V., Revilla, E. and Choi, T., 2011. The dark side of buyer-supplier relationships: a social capital perspective. Journal of Operations Management, Vol. 29, pp. 561-576.

Wang, C. L. and Ahmed, P. K., 2004. The Development and Validation of the Organisational Innovativeness Construct Using Confirmatory Factor Analysis. European Journal of Innovation Management, Vol. 7, No. 4, pp. 303-313.

Wang, Q.; Bradford, J.X. and Weitz, B., 2008. Creativity in buyer-seller relationships: The role of governance. International Journal of Research in Marketing, Vol. 25, No. 2, pp. 109-118.

Williamson, O. E., 1985. The Economic Institutions of Capitalism. New York: The Free Press. 
Figure 1. Conceptual framework

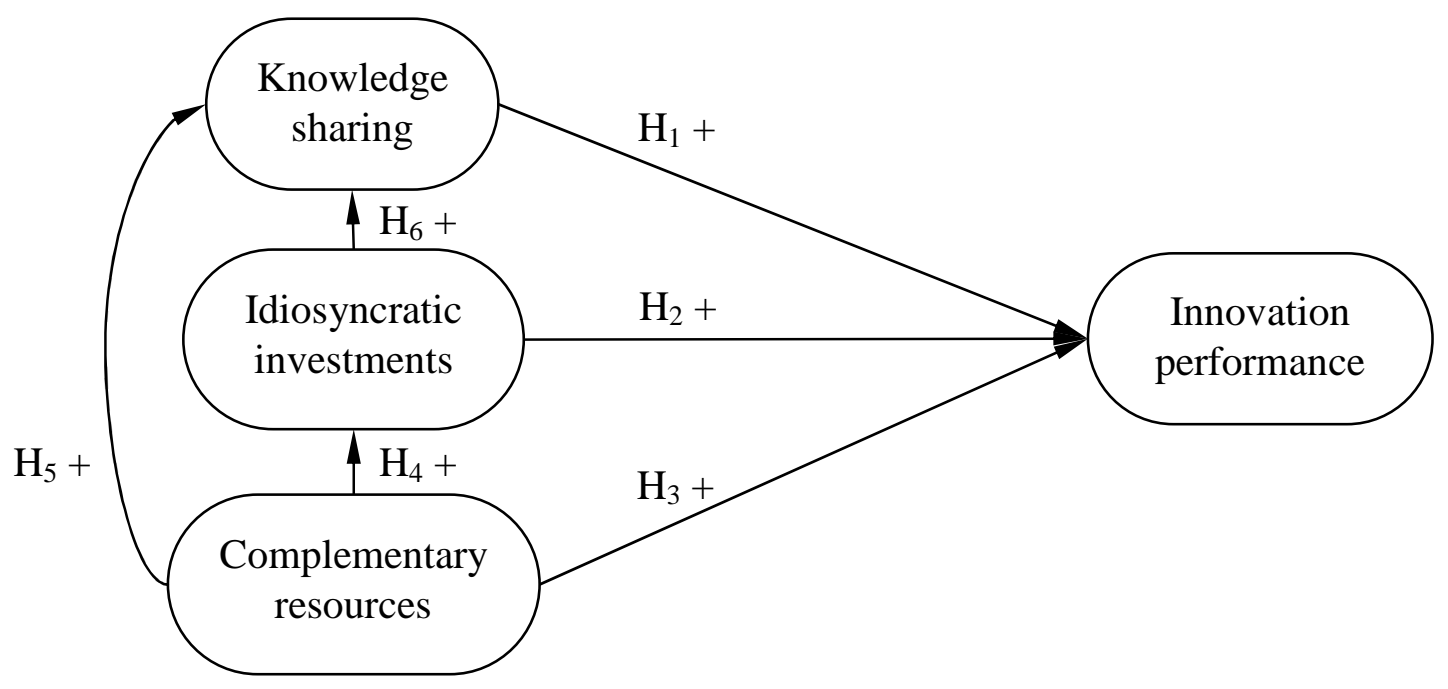


Table 1. Descriptive values obtained from the sample

\begin{tabular}{|c|c|c|}
\hline Variable & & Result \\
\hline \multirow[t]{2}{*}{ Relationship role } & As sellers & 97 \\
\hline & As buyers & 105 \\
\hline \multirow{5}{*}{$\begin{array}{r}\text { Duration of } \\
\text { relationship in years }\end{array}$} & Since 2008 & $5.0 \%$ \\
\hline & Since 2006-2007 & $4.5 \%$ \\
\hline & Since $2003-2005$ & $11.3 \%$ \\
\hline & Since $2000-2002$ & $17.3 \%$ \\
\hline & Since before 2000 & $61.9 \%$ \\
\hline \multirow{10}{*}{$\begin{array}{l}\text { Industries with } \\
\text { which they are } \\
\text { mainly involved }\end{array}$} & Industrial equipment and machine industry & \\
\hline & in general & $35.3 \%$ \\
\hline & Motor and motor parts industry & $11.3 \%$ \\
\hline & Dies and moulds & $6.0 \%$ \\
\hline & Food industry & $5.3 \%$ \\
\hline & Textile industry & $4.0 \%$ \\
\hline & Aero-space construction & $2.3 \%$ \\
\hline & Wood & $2.3 \%$ \\
\hline & Plastic materials & $1.3 \%$ \\
\hline & Other & $32.2 \%$ \\
\hline \multirow[t]{9}{*}{ Country } & Germany & 73 \\
\hline & Italy & 38 \\
\hline & Portugal & 22 \\
\hline & Spain & 16 \\
\hline & Switzerland & 14 \\
\hline & France & 15 \\
\hline & UK & 7 \\
\hline & Austria & 5 \\
\hline & Finland & 4 \\
\hline \multirow{2}{*}{$\begin{array}{r}\text { Company size by } \\
\text { number of employees }\end{array}$} & Small: Less than 100 & 95 \\
\hline & Large: Equal to or more than 100 & 107 \\
\hline
\end{tabular}


Table 2. Adjustment results of factors used

Innovation performance

INP1: Thanks to the incorporated innovations, the product sold to this customer/purchased from this supplier enables us to achieve exceptional quality or utilities in the sector.

INP2: Thanks to the incorporated innovations, the machine sold/ purchased provides us with a

significant competitive edge.

Knowledge-sharing routines

KSR1: Our technical experts provided substantial information and specific knowledge to our customer/supplier, which was of great use in order to improve our product.

KSR2: We believe that good innovative ideas followed from the suggestions or demands that we make or made on our customer/supplier.

KSR3: We have or had frequent interviews with this customer/supplier, at which we put forward useful information for improving the machine that we sold/purchased.

Idiosyncratic (rel.specific) assets

REA1: For the particular case of the relationship we had or have with this customer/supplier, our company's technical staff has had to acquire and apply specific knowledge which could hardly be used with another customer/supplier.

REA2: We made specific investments in assets, patents, software or personnel, so as to better meet this customer's needs/so that this supplier can adequately meet our needs.

REA3: Both the client/supply company and our company have made specific investment in order to obtain improvements in the machine we sold them/purchased.

\section{Complementary R\&C}

RCE1: Our company and the client/supply company share or shared resources and abilities, which, once combined, allow both companies to achieve objectives which go beyond what individually we could attain on our own.

RCE2: We provide resources and abilities which complement those of the customer/supplier and are or were beneficial to the relationship, and which we can/could recover for alternative uses, thus not losing significant value.

RCE3: Our own company shares/shared resources and abilities which, combined with those of the client/supply company, enable/enabled us to achieve objectives that go beyond what we could attain on our own.

RCE4: We provided the client/supply company with the opportunity to use our resources (such as plants, technology, software or machinery), which we can still use for other alternative purposes we may decide on

\section{Standzd.}

loadings

Robust

value

$9.099^{* * *}$

0.802

$9.130^{* * *}$

0.763

0.641

0.781

$0.670 \quad 8.547^{* * *}$

$0.605 \quad 7.463^{* * *}$

$0.667 \quad 8.298^{* * *}$

0.633

0.420

0.684

$0.719 \quad 13.416^{* * *}$

$0.831 \quad 14.441^{* * *}$

$\begin{array}{llll}0.741 & 12.083^{* * *} & 0.805 & 0.586\end{array}$

0.808

reliability

alpha

$\mathrm{AVE}^{(1)}$

Composite 
Table 3. Validation of the final measurement model - Discriminant validity

F1

F2

F3

F4

Innovation Performance

0.801

0,572

0,167

0,120

Knowledge-Sharing

$(0.415 ; 0.729)$

0.648

0.675

0.510

Idiosyncratic Investments

$(-0.011 ; 0.505)$

$(0.540 ; 0.810)$

0.765

0.871

Complementary Resources

$(-0.051 ; 0.291) \quad(0.361 ; 0.659)$

$(0.808 ; 0.934)$

0.832

Notes: The diagonal represents the square root of the average variance extracted. Above the diagonal, the shared variance (in correlations) are represented. Below the diagonal are the 95\% confidence intervals for the estimated factor correlations. 
Table 4. Tests of measurement invariance

\begin{tabular}{|c|c|c|c|c|c|c|c|c|c|c|c|c|}
\hline & $\chi^{2 \dagger}$ & $\chi_{\text {S-B }}^{2} \dagger$ & $d f$ & $\Delta \chi^{2}$ & $\Delta d f$ & $p$ & $\Delta \chi_{\text {S-B }}^{2}$ & $p_{\text {S-B }}$ & $\operatorname{RMSEA}(90 \% \mathrm{CI})$ & SRMR & CFI & TLI(NNFI) \\
\hline $\begin{array}{l}\text { Single groups: } \\
\text { Buyers }(n=95)\end{array}$ & $\begin{array}{c}69.383 \\
(p=0.023)\end{array}$ & $\begin{array}{c}64.685 \\
(p=0.054)\end{array}$ & 48 & & & & & & $0.073(0.028,0.108)$ & 0.057 & 0.955 & 0.938 \\
\hline Sellers $(n=97)$ & $\begin{array}{c}72.641 \\
(p=0.012)\end{array}$ & $\begin{array}{c}64.653 \\
(p=0.055)\end{array}$ & 48 & & & & & & $0.078(0.037,0.113)$ & 0.064 & 0.958 & 0.942 \\
\hline $\begin{array}{l}\text { Measurement invariance: } \\
\text { Equal form (base model) }\end{array}$ & $\begin{array}{c}142.023 \\
(p=0.002)\end{array}$ & $\begin{array}{c}129.328 \\
(p=0.013)\end{array}$ & 96 & & & & & & $0.076(0.047,0.100)$ & 0.061 & 0.957 & 0.941 \\
\hline Equal factor loadings & $\begin{array}{c}145.132 \\
(p=0.010)\end{array}$ & $\begin{array}{c}136.701 \\
(p=0.032)\end{array}$ & 108 & 3.109 & 12 & 0.995 & 4.044 & 0.983 & $0.064(0.033,0.089)$ & 0.071 & 0.965 & 0.957 \\
\hline Structural model invariance & $\begin{array}{c}146.757 \\
(p=0.011)\end{array}$ & $\begin{array}{c}136.943 \\
(p=0.042)\end{array}$ & 110 & 4.734 & 14 & 0.989 & 5.322 & 0.981 & $0.063(0.031,0.088)$ & 0.072 & 0.966 & 0.959 \\
\hline
\end{tabular}

Note: $\mathrm{N}=202$. RMSEA, root mean square error of approximation; 90\%CI, 90\% confidence interval for RMSEA; SRMR, standardized root mean square residual; CFI, comparative fit index; TLI,

Tucker-Lewis Index; NNFI, Bentler-Bonet non-normed fit index

$\dagger$ Maximum-Likelihood adjusted Chi-Square values; $\dagger \dagger$ Satorra-Bentler adjusted Chi-Square values 
Table 5. Regression Coefficients, $t$ values, and Model Summary Information for the Serial Multiple Mediator Model depicted in Figure 1:

\begin{tabular}{|c|c|c|c|c|c|c|c|}
\hline \multirow[b]{3}{*}{ Hipothesis } & \multirow{3}{*}{$\begin{array}{l}\text { Total } \\
\begin{array}{l}\text { Direct (i.e. from } \mathrm{H}_{1} \text { to } \mathrm{H}_{6} \text { ) and indirect } \\
\text { effects (rest of lines) }\end{array}\end{array}$} & \multicolumn{2}{|c|}{ Total sample model $\ddagger$} & \multicolumn{4}{|c|}{ Two-sample model $\ddagger \bullet$} \\
\hline & & \multirow[b]{2}{*}{$\begin{array}{l}\text { Stand. } \\
\text { Coeff. }\end{array}$} & \multirow[b]{2}{*}{$\begin{array}{c}\text { Two-tailed } \\
t\end{array}$} & \multicolumn{2}{|c|}{ Buyers } & \multicolumn{2}{|c|}{ Sellers } \\
\hline & & & & $\begin{array}{l}\text { Stand. } \\
\text { Coeff. }\end{array}$ & $\begin{array}{c}\text { Two-tailed } \\
t\end{array}$ & $\begin{array}{l}\text { Stand. } \\
\text { Coeff. }\end{array}$ & $\begin{array}{c}\text { Two-tailed } \\
t\end{array}$ \\
\hline $\mathrm{H}_{1}$ & KnowShar $\rightarrow$ InnPerf & 0.868 & $3.849^{* * *}$ & 1.182 & $3.190^{* *}$ & 1.109 & $3.189^{* *}$ \\
\hline $\mathrm{H}_{2}$ & $I d I n v \rightarrow I n n P e r f$ & -0.570 & -1.511 & -1.044 & -1.588 & -1.033 & -1.581 \\
\hline $\mathrm{H}_{3}$ & ComplRes $\rightarrow$ InnPerf & 0.174 & 0.619 & 0.360 & 0.791 & 0.366 & 0.791 \\
\hline $\mathrm{H}_{4}$ & ComplRes $\rightarrow$ IdInv & 0.871 & $9.604^{* * *}$ & 0.872 & $10.236^{* * * *}$ & 0.893 & $10.232^{* * * *}$ \\
\hline $\mathrm{H}_{5}$ & ComplRes $\rightarrow$ KnowShar & -0.323 & -1.252 & -0.604 & $-1.953^{*}$ & -0.653 & $-1.954^{*}$ \\
\hline \multirow[t]{6}{*}{$\mathrm{H}_{6}$} & $I d I n v \rightarrow$ KnowShar & 0.956 & $3.375^{* * *}$ & 1.219 & $3.498^{* * *}$ & 1.286 & $3.494^{* * *}$ \\
\hline & ComplRes $\rightarrow$ KnowShar $\rightarrow$ InnPerf & -0.280 & -1.160 & -0.714 & -1.610 & -0.725 & -1.605 \\
\hline & ComplRes $\rightarrow$ IdIn $v \rightarrow$ InnPerf & -0.496 & -1.484 & -0.910 & -1.560 & -0.923 & -1.558 \\
\hline & ComplRes $\rightarrow$ IdInv $\rightarrow$ KnowShar & 0.833 & $3.272^{* * *}$ & 1.063 & $3.375^{* * *}$ & 1.148 & $3.377^{* * *}$ \\
\hline & IdInv $\rightarrow$ KnowShar $\rightarrow$ InnPerf & 0.830 & $2.382^{* *}$ & 1.441 & $2.086^{*}$ & 1.426 & $2.083^{*}$ \\
\hline & ComplRes $\rightarrow$ IdInv $\rightarrow$ KnowShar $\rightarrow$ InnPerf & 0.723 & $2.449^{*}$ & 1.256 & $2.296^{*}$ & 1.274 & $2.296^{*}$ \\
\hline
\end{tabular}

$\mp \chi_{\text {S-B }}^{2}(\mathrm{df}=48)=66.460(p=0.040) ; \mathrm{RMSEA}=0.046(0.010,0.071) ; \mathrm{CFI}=0.983 ; \mathrm{TLI}=0.976$

$\ddagger \cdot \chi_{\mathrm{S}-\mathrm{B}}^{2}(\mathrm{df}=110)=146.757(p=0.011) ; \mathrm{RMSEA}=0.063(0.031,0.088) ; \mathrm{CFI}=0.966 ; \mathrm{TLI}=0.959$

$* p<0.1 ; * * p<0.01 ; * * * p<0.001$ 
